\title{
Hedging, managerial ownership and firm value
}

\author{
Zaminor Zamzamir@Zamzamin \\ Universiti Malaysia Kelantan, Pengkalan Chepa, Malaysia, and \\ Razali Haron and Anwar Hasan Abdullah Othman \\ International Islamic University Malaysia, \\ IIUM Institute of Islamic Banking and Finance, Kuala Lumpur, Malaysia
}

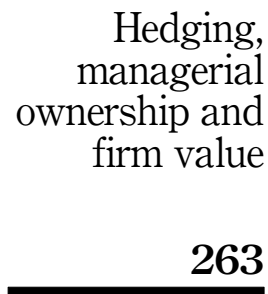

Received 22 August 2020 Revised 17 November 2020 18 March 2021

Accepted 23 March 2021

\begin{abstract}
Purpose - This study investigates the impact of derivatives as risk management strategy on the value of Malaysian firms. This study also examines the interaction effect between derivatives and managerial ownership on firm value.

Design/methodology/approach - The study examines 200 nonfinancial firms engaged in derivatives for the period 2012-2017 using the generalized method of moments (GMM) to establish the influence of derivatives and managerial ownership on firm value. The study refers to two related theories (hedging theory and managerial aversion theory) to explain its findings. Firm value is measured using Tobin's $Q$ with return on assets (ROA) and return on equity (ROE) as robustness checks.

Findings - The study found evidence on the positive influence of derivatives on firm value as proposed by the hedging theory. However, the study concludes that managers less hedge when they owned more shares based on the negative interaction between derivatives and managerial ownership on firm value. Hedging decision among managers in Malaysian firms therefore does not subscribe to the managerial aversion theory.

Research limitations/implications - This study focuses on the derivatives (foreign currency derivatives, interest rate derivatives and commodity derivatives) and managerial ownership that is deemed relevant and important to the Malaysian firms. Other forms of ownership such as state-/foreign owned and institutional ownership are not covered in this study.

Practical implications - This study has important implications to managers and investors. First is on the importance of risk management using derivatives to increase firm value, second, the influence of derivatives and managerial ownership on firm value and finally, the quality reporting on derivatives exposure by firms in line with the required accounting standard.

Originality/value - There is limited empirical evidence on the impact of derivatives on firm value as well as the influence of managerial ownership on hedging decisions of Malaysian firms. This study analyzes the influence of derivatives on firm value during the period in which reporting on derivatives in financial reports is made mandatory by the Malaysian regulator, hence avoiding data inaccuracy unlike the previous studies on Malaysia. This study therefore fills the gap in the literature in relation to the risk management strategies using derivatives in Malaysia.
\end{abstract}

Keywords Derivatives, Managerial ownership, Firm value, Hedging theory, Managerial aversion theory Paper type Research paper

\section{Introduction}

Many firms and financial institutions collapsed during the 1997 East Asian financial crisis and subsequently the 2007/2008 global financial crisis due to poor risk management (Siddika and Haron, 2020). Following this, financial derivatives have become extremely popular as a hedging instrument among the nonfinancial firms for risk management (Ayturk et al., 2016).

\section{JEL Classification - G32, L25, O16}

(C) Zaminor Zamzamir@Zamzamin, Razali Haron and Anwar Hasan Abdullah Othman. Published in Journal of Asian Business and Economic Studies. Published by Emerald Publishing Limited. This article is published under the Creative Commons Attribution (CC BY 4.0) licence. Anyone may reproduce, distribute, translate and create derivative works of this article (for both commercial and non-commercial purposes), subject to full attribution to the original publication and authors. The full terms of this licence may be seen at http://creativecommons.org/licences/by/4.0/legalcode.

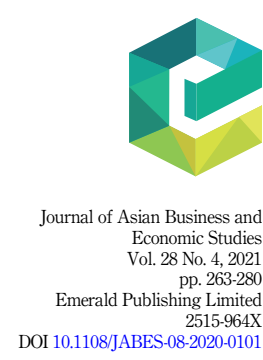


JABES 28,4
For instance, $59 \%$ of firms in Sweden (Alkebäck et al., 2006), 78\% in Hong Kong and Singapore (Sheedy, 2006) and 61.6\% in Denmark, Finland, Iceland and Sweden (Brunzell et al., 2011) use derivatives to manage risk.

While hedging through derivatives is believed to be an effective and essential risk management strategy, empirical evidence on the matter remains mixed (Seok et al., 2020). Bhagawan and Lukose (2017) reported that firms with higher foreign exchange exposures engage in more derivatives positions for hedging purposes. Furthermore, Belghitar et al. (2013) found that derivatives instruments are effective in reducing foreign currency risk exposures, while Bouwman (2014) stated that firms use derivatives as effective risk management tool. In relation to this, Antônio et al. (2019) reported that firms use derivatives for protection. Moreover, Barton (2001) claimed that managers use derivatives to mitigate the effect of risk exposure as managers need to maintain high profit for the firms. In contrast, Brunzell et al. (2011) claimed that firms use derivatives for profit more than for hedging. Bodnar et al. (1998) stated that derivatives are often used for profit seeking and used by various parties that are unable to diversify the risk associated with the firm. Among these parties, managers are the ones who most likely involve in derivatives decision-making. Nguyen and Faff (2002) stated that managers decide on financial derivatives use. Smith and Stulz (1985) assumed that the wealth of the manager is a concave function of the valuation of the firm, thus is best for them to hedge to protect the firm value. Lievenbrück and Schmid (2014) reported that managers are inclined toward engaging in derivative hedging. This is in line with Adam and Fernando (2006) who found that firm value increased due to manager's decision to hedge and being active in hedging activities. Furthermore, Fahlenbrach and Stulz (2009) found that higher ownership by managers benefits the firm, which encourages them in taking up active hedging strategies. Seok et al. (2020) found Korean firms use derivatives to manage operational volatility rather than to manage market risk. However, Berkman and Bradbury (1996) did not find any clear support for a positive relationship between managerial ownership and hedging decision.

Bartram (2019) reported that firms in the USA, the UK, Australia, Canada and New Zealand as well as firms in other countries that comply with the International Accounting Standard (IAS) are mandatory to reveal information on their derivatives position. Malaysia is also no exception to mandatory disclose the information on derivatives position. In November 2011, the Malaysian Accounting Standard Board (MASB) issued the Malaysian Financial Reporting Standard (MFRS) 7 (Financial Instrument: Disclosure). The effective date for firms in Malaysia to follow the standard is on or after January 2012. This information disclosure standard has severe implications as the studies on derivatives using Malaysian data prior to 2012 may suffer from data inaccuracy since the reporting on hedging positions was not made mandatory prior to the period. This means some firms may not report their hedging positions, although they may be engaged in derivatives during that period. The MFRS 7 is corresponding to the International Financial Reporting Standard (IFRS) 7 (Financial Instrument: Disclosure), issued by the International Accounting Standard Board (IASB). Meanwhile, in July 2014, MASB issued the MFRS 9 (Financial Instrument: Recognition and Measurement). The MFRS 9 is in line with the IFRS 9 (Financial Instrument: Hedge Accounting), and the IFRS 9 is applied to financial statements of Malaysian firms beginning on or after January 1,2018. According to the Securities Commission (SC) of Malaysia, after the global financial crisis of 2007/2008, the IFRS announced the guideline for public listed firms to publish sufficient information in the financial reports to restore investors' confidence. In this regard, MASB requires listed firms to follow the IFRS for their reporting standard and firms have to disclose their derivatives positions to comply with the listing requirement. Based on the reporting standard, Malaysian listed firms must disclose information on derivatives contracts in their financial statements, specifically in the off-balance sheet section. This guideline is consistent with the IFRS 7 and IFRS 9, which requires listed firms to report their 
motivation for derivatives usage as it accords with their hedging exposure. However, despite this requirement, Abdullah and Ismail (2017) found that only 54\% (162 companies) out of 300 Malaysian listed firms use derivatives for hedging activities. Besides, Lau (2016) recorded that only $26.8 \%$ (182 companies) from 680 Malaysian public listed firms utilize the derivatives contracts, while the rest of 498 firms did not use any derivatives during the period 2002-2012. Fazillah et al. (2008) reported only $29 \%$ (101 out of 352) of Malaysian nonfinancial listed firms hedged over the period from 2001 to 2005 . Meanwhile, $36.41 \%$ of the listed firms are reported to engage and use derivatives instruments to hedge financial risk as reported in the Turkey market (Ayturk et al., 2016).

The Malaysian derivatives market has gone through a series of structural and operational changes since 1995. Macroeconomic event such as the Asian financial crisis of 1997/1998 shaped the scope of derivatives instruments in the Malaysian market. The revolution of Malaysian Derivatives Exchange (MDEX) began in December 2001, where the MDEX was converted from traditional to fully electronic derivatives exchange. Then in March 2002, it introduced the five-year government bond futures and became Malaysia's first bond futures contract to be traded in the derivatives market. In September 2003, other futures contracts, which are the three years and 10 years bond futures were launched. In April 2006, a single stock index futures contract was introduced. Next, the Malaysia Capital Market and Services Act was introduced in 2007 and revised in 2011, in order to allow the SC of Malaysia to standardize the derivatives and over-the-counter (OTC) derivatives. Following this, commodity, equity and financial derivatives which are exchange traded derivatives were offered by Bursa Malaysia except for foreign currency. This is because foreign currency derivatives that include forex swap, forwards and options were traded in the OTC market. Finally, MDEX is later known as the Bursa Malaysia Derivatives Berhad (BMD).

The literature records that shareholders have an intense interest in managing risk of the firm. Despite this, there is a lack of information on the use of derivatives by firms for risk management and this becomes a constraint for shareholders to estimate their risk exposure in the firm (Ghosh, 2017). For instance, in the case of the US\$2bn loss of JPMorgan Chase Bank due to the trading of credit default swaps in 2012 and the bailout in 2008 by the US government on American International Group (AIG) following the huge loss on derivatives exposure, contributed by the lack of information disclosure in derivatives. This shows that information disclosure is crucial and regulators should put more effort in enforcing regulations related to derivatives. Ameer et al. (2011) discovered in their survey that there is a lack of exposure on derivatives among Malaysian firms. Adding to this, derivatives are considered to be costly and complex products. Ameer (2010) reported that most of the Malaysian managers tend to be risk-averse and do not realize the benefit of hedging from the derivative markets. Furthermore, Ameer found that many firms did not use derivatives for risk management because of the lack of expertise among managers in handling derivatives products. Most of the firms have difficulty in understanding complex derivatives, and this, thus, hinders them from hedging activities. In addition, the transaction cost associated with derivatives contracts is also a concern for managers. Furthermore, Ameer (2010) revealed that most of the Malaysian firms have insufficient risk management strategies and do not engage in any form of hedging instruments to hedge market risk.

This study however differs from Ameer (2010) in several aspects. First, Ameer focused on firm-specific determinants that may influence the use of derivatives among Malaysian firms, while the current study examines the influence of derivatives on the value of firms in Malaysia. Second, this study also incorporates the role of managerial ownership in derivatives which eventually influences firm value. In this regard, an endogeneity problem in panel data is addressed using an appropriate model with instrumental variable unlike Ameer and most of other studies on derivatives using Malaysian data where simple ordinary 
JABES 28,4

266 least squares (OLS) regression is performed. Seok et al. (2020) emphasize the importance of controlling endogeneity for studies on hedging due to the existence of endogeneity problem between hedging and firm value. They stressed further that mixed results in past studies on hedging and firm value could mainly be explained by endogeneity. Endogeneity problem according to Seok et al. is due to, first, the omitted control variables that determine firm value; second, the fact that hedging depends on past data on firm value; hence, it is not strictly exogenous and third, the unobservable firm-specific factors in the regression model. Due to its importance, Maggie (2013), Bartram et al. (2011) and Seok et al. (2020) employed appropriate model with instrumental variable to control for endogeneity.

Lastly and most importantly, most of the past studies on Malaysia including Ameer (2010) suffered from data inaccuracy since the reporting on hedging positions was not made mandatory prior to 2012. This means some firms may not report their hedging positions, although they may be engaged in derivatives during the period under study.

Centered on the above arguments, this study is motivated based on first, there is a lack of empirical evidence on the use of derivatives and the role of managerial ownership and its impact on the value of Malaysian firms. Second, almost all past studies conducted on Malaysia suffered from endogeneity problem since the models used in the studies did not address endogeneity issues. Third, this study analyzes the influence of derivatives on firm value during the period in which reporting on derivatives in financial reports of firms is made mandatory by the SC of Malaysia. Considering these motivations, this study therefore aims to examine the impact of derivatives on the value of firms. This study also examines the effect of derivatives together with the influence of managerial ownership on hedging decision on firm value. This study therefore fills the gap in the literature in relation to the risk management strategies using derivatives in the context of Malaysian firms.

\section{Literature review}

There are a lot of studies on hedging. It started with the classical paradigm theory introduced by Modigliani and Miller, which stated that the decisions on financial policy only impact firm value (Modigliani and Miller, 1958). However, the Modigliani-Miller (MM) theory contradicts with later scholars on risk management practices. Some researchers recommend that hedging that uses derivatives is a value-increasing strategy for the firm. Hedging refers to activities undertaken by a firm to mitigate the impact of uncertainties on the value of the firm (Mian, 1996). The hedging theory is first discussed by Stulz (1984). He stated that if external financing is more costly than internal financing, hedging is a value-enhancing activity. This is if it closely matches fund inflows with outflows and decreases the probability that a firm needs to access the capital market. Hedging ensures that a firm has sufficient internal funds to avoid unnecessary fluctuations of risk, thus increasing firm value. Demarzo and Duffie (1995) specified that tax incentives, underinvestment cost, financial distress and managerial compensation could increase the firm value through hedging. Allayannis and Ofek (2001) reported that the inaccessibility of data on hedging activities causes the lack of empirical investigation on hedging. Furthermore, in the early 1990s, information on derivatives positions in firms was confidential and it was considered a strategic competitiveness component. Recently, firms are required to disclose all information (risk management and financial derivatives) in the footnote of their annual reports in off-balance sheet section. Researchers have to use data reported in the off-balance sheet of financial statements to examine the value relevance and the usage of derivatives for hedging. Geczy et al. (1997) analyzed the use of currency derivatives and found that firm that exposes to risk tends to use currency derivatives to increase firm value.

Managerial aversion theory explains the management motivation for corporate hedging. Proposed by Stulz (1984), it states that a manager is the one who decides the hedging policy of 
the firm, not the shareholder. In addition, Smith and Stulz (1985) reported that managers prefer to use derivatives to control firm risk and to shield themselves from any uncertainties. They also mentioned that the advantage of using derivatives is to reduce risk due to poor diversified human capital stake and wealth invested in the firm. Besides, based on the risk aversion assumption, the enhancement of firm value is according to the reduction of risk as shareholders like to invest in certain outcomes (Gastineau and Kritzman, 1999). Thus, the decreasing risk via hedging can increase firm value. Mian (1996) also found varied evidence on the managerial aversion theory when he examined the three types of hedging (derivatives - currency, interest rate and commodity). The study concludes that managers are more likely to hedge if they are given higher incentives. At the same time, regulator plays important role to make it easier for managers to claim the incentives. Thus, managers take less hedging positions when they have less incentive and hedge when more incentives are given to them.

Recent empirical studies link a variety of firm performance to hedging with the evidence available for both ends of the debate. Bhagawan and Lukose (2017) reported that to hedge currency exposure, firms are more likely to use derivatives. This is in line with Chong et al. (2014) who found that the use of derivatives is to minimize risk, hence increasing firm value. Besides, Allayannis and Weston (2001) claimed that foreign currency derivatives and firm value is positively significant. They also recorded that firm value is exposed to currency risk and the use of derivatives among the firms is able to create higher firm value compared to the nonuser of derivatives firms. Tanha and Dempsey (2017) also found that financial risk (such as interest rates, foreign exchange, equity) and commodity risk have influence on firms to hedge. Besides, Bartram et al. (2011) also found a positive relationship between the use of derivatives and firm value. They examined the effect of hedging on risk and firm value of 47 countries with a sample on nonfinancial firms and found evidence on the value relevance issue. Conversely, Bae et al. (2017) in their study on firms in the manufacturing and services industries in Korea found that foreign currency derivatives fail to increase firm value. In another study by Bae and Kim (2016), it was reported that the heavy usage of foreign currency derivatives by Korean firms leads to lower firm risk. However, it failed to increase firm value due to inefficient hedging practices of the firms. Their finding is in support of Magee (2013), who found no relationship between foreign currency derivatives and firm value. Belghitar et al. (2013) also found that there is no significant influence of foreign currency on firm value in the sample of French nonfinancial firms. Seok et al. (2020) in their studies on Korean manufacturing firms found active hedgers use derivatives more efficiently compared to moderate hedgers.

Risk management practices have attracted manager's attention. In this regard, there is a mixed result on the effect of managerial ownership on firm value. According to Adam and Fernando (2006), shareholders' value increased due to the manager's decision to be active in hedging activities. The study also found that the manager's market view influences risk management decision. Lel (2012) stated that a firm with strong corporate governance tends to use foreign currency derivatives to hedge currency risk but weak firm's governance acts differently. Coles et al. (2012) also found that managerial ownership could maximize firm value, consistent with Fahlenbrach and Stulz (2009) that found higher ownership held by managers is valuable for firm value.

In the Malaysian context, managerial ownership leads to higher usage of derivatives as recorded by Ameer (2010), who found a significant relationship between managerial ownership and firms that engage in derivatives. This is because managers try to reduce the risk affecting the return on their investment in the firms. Unlike managerial ownership, the study reported that institutional ownership has a significant negative relationship with firm value. Seng and Thaker (2018) examined the relationship between managerial ownership and corporate hedging in Malaysia. Managers are found to take less hedging positions when they owned more shares, hence confirming a significant negative relationship between managerial 
JABES 28,4

\section{8}

ownership and corporate hedging. It is similar to Supanvanij and Strauss (2010) who reported that hedging is negatively related to managerial ownership. Meanwhile, Haushalter (2000) found that there is no evidence on the effect of managerial ownership on corporate hedging, in line with Nguyen and Faff (2002) who studied the nonfinancial firms in Australia. Haushalter (2000) and Nguyen and Paff (2002) highlighted that low managerial ownership in their sample firms could be the reason of the insignificant evidence of ownership on hedging. Notwithstanding such varied findings on empirical evidence of derivatives use among the firms and in support of the hedging theory and managerial aversion theory, this study hence hypothesizes that

H1. There is a significant positive relationship between hedging via derivatives and firm value, as proposed by the hedging theory.

H2. There is a significant positive relationship between derivatives and managerial ownership (interaction) that influences firm value, as proposed by the managerial aversion theory.

\section{Research methodology and data}

\subsection{Sample selection}

The sample data of this study involve nonfinancial firms from the various sectors which include consumer products, construction, industrial products, plantations, properties, technology and trading and services. These firms engaged in derivatives from 2012 to 2017 by referring to their annual reports at the off-balance sheet section in accordance with the standard reporting of financial instruments and disclosure of the MFRS 7 (Financial Instrument: Disclosure). This study begins with 2012 because starting from January 2012, reporting on derivatives in financial reports of firms is made mandatory by the SC of Malaysia in line with the MFRS 7. There are 946 firms listed in the main market of Bursa Malaysia as at December 2017. Out of these firms, only firms that engaged in derivatives are chosen, and the engagement in derivatives is irrespective of any years during the study period. Therefore, after the filtering process, among the listed firms in Bursa Malaysia, only 200 firms are engaged in derivatives positions. The financial reports were downloaded from Bursa Malaysia's website in electronic format. The information on firms with derivatives positions is scanned by using the following keywords in the annual reports: risk management, derivatives, foreign exchange forward, forward foreign exchange, forward contract and forward exchange contract.

\subsection{Dependent variable}

Tobin's $Q$ acts as a proxy for the dependent variable representing firm market value, and it is a common measurement to be used for firm value (Ayturk et al., 2016). Tobin's $Q$ is described as the total market capitalization of common stocks plus preferred stocks and total debt divided with the total asset. Preferred stock refers to the liquidating value of the firm's outstanding preferred stock which is part of the firm value (Chung and Pruitt, 1994).

$$
Q=\frac{\text { Market capitalization }(\text { Common stocks })+\text { Preferred stocks }+ \text { Total debt }}{\text { Total asset }}
$$

The above formula is consistently used by other researchers such as Allayannis et al. (2011), Allayannis and Ofek (2001), Bartram et al. (2011), Lau (2016), Ayturk et al. (2016) and Bae et al. (2017). Seok et al. (2020) argued that Tobin's $Q$ is widely used as a measurement of firm value in accounting, economics and finance literature. They stated that Tobin's $Q$ does not only reflect past performance but also represents the firm's future development expectations. 
Moreover, Dakhlallh et al. (2020) also mentioned that Tobin's $Q$ is an effective measurement to analyze corporate performance from a long-term market view, thus reflecting the present value of future cash flows based on current and future information. Thus, this paper employs Tobin's $Q$ to measure firm value. Data on firms (except derivatives positions and managerial ownership) are collected from Datastream database.

\section{Hedging, managerial ownership and firm value}

\subsection{Explanatory variables}

The explanatory variables for this study are total derivatives engaged by the firms and managerial ownership during the study period. Total derivatives are the sum of foreign currency derivatives, interest rate derivatives and commodity derivatives. Based on data extraction from the annual reports, these are the only types of derivatives engaged by Malaysian firms during the period under study. The proxy of derivatives is a continuous variable and is measured by notional value of the derivatives contracts $(\mathrm{RM})$ at the fiscal year divided by total asset, similar to Allayannis and Ofek (2001), Lel (2012), Nguyen and Faff (2010), Magee (2013), Ayturk et al. (2016) and Seok et al. (2020). This study employed notional value because first, Malaysian firms report their hedging activities (derivatives) as notional value in the annual reports (risk management section). Second, the use of notional value is widely used in the literature. Third, nominal value follows IFRS on hedging accounting rules where the firms have to recognize the changes in the value of derivatives at each financial reporting stage such as assets, liability or equity.

Meanwhile, managerial ownership also acts as an explanatory variable. The measurement of managerial ownership is the total shareholding (direct) owned by executive directors (managers) over the total common shares outstanding at the end of each year in the firm, in line with Ameer (2010) and Haron (2018). Data on explanatory variables are manually collected from the annual reports of the firms.

\subsection{Control variables}

A total of five control variables are included to explain the firm's value:

\section{(1) Access to financial market}

If firms forgo projects because they are unable to obtain the necessary financing, their firm value remains high because only positive net present value (NPV) projects are being pursued. Lau (2016), Allayannis and Weston (2001) and Magee (2013) stated that firms paying dividends are less likely to face capital constraints and can reduce its dividend to increase investment. Following Law (2016) and Seok et al. (2020), the proxy for the access to the financial market is firm that pays dividend in the present year equals to " 1 " and " 0 " otherwise.

(2) Firm risk

Past studies reported that heavy usage of foreign currency derivatives by Korean firms leads to lower firm risk and higher firm value (Bae et al., 2017). Choi et al. (2013) also found that firms engaged in derivatives have lower equity return volatility. Following these studies, the measurement of firm risk is based on the average standard deviation of daily stock returns on the previous year and then annualized to yearly return.

\section{(3) Firm size}

Firm size is found to have influence on firm value. Past studies reported that firm size has a positive significant relationship with hedging decision and hence increases firm value (Allayannis et al., 2011; Lau, 2016; Magee, 2013). However, Allayannis and Weston (2001) and Ayturk et al. (2016) found that firm size negatively related to firm value. The proxy for the firm size is the natural logarithm of total assets. 
JABES

28,4

270

(4) Investment growth

Firms tend to have a large investment and depend on future investment opportunities to grow. The growth eventually influences firm value. This study follows Allayannis and Weston (2001) and Seok et al. (2020) by using the ratio of capital expenditure to sales as a measurement for investment growth.

(5) Leverage

The capital structure of the firms affects firm value. Thus, to control for capital structure, this study uses long-term debt divided by total shareholder's equity. This is similar to Allayannis et al. (2011), Ayturk et al. (2016) and Seok et al. (2020).

\section{Generalized method of moments (system-GMM)}

This study begins with model 1 on the relationship between firm value and derivatives and managerial ownership with control variables, written in a panel data form as follows:

$$
\begin{aligned}
Q_{i t}= & \beta_{0}+\beta_{1} Q_{i t-1}+\beta_{1} \mathrm{DER}_{i t}+\beta_{2} \mathrm{MO}_{i t}+\beta_{3} \mathrm{ACCES}_{i t}+\beta_{4} \mathrm{RISK}_{i t} \\
& +\beta_{5} \mathrm{SIZE}_{i t}+\beta_{6} \mathrm{GROWTH}_{i t}+\beta_{7} \mathrm{LEV}_{i t}+\eta_{i}+\varepsilon_{i t}
\end{aligned}
$$

where $Q_{i t}$ is firm value, measured by Tobin's $Q$ for firm $i$ in period $t$. To capture the persistence in firm value, the lagged value of Tobin's $Q$ is included as an independent variable. The explanatory variables are $\mathrm{DER}_{i t}$ (derivatives) and $\mathrm{MO}_{i t}$ (managerial ownership). The control variables consist of ACCES $_{i t}$ which is access to financial market, RISK $_{i t}$ is a firm risk, SIZE $i t$ is a firm size, GROWTH ${ }_{i t}$ as investment growth and $\mathrm{LEV}_{i t}$ is leverage, while $\eta_{i}$ is an unobserved firm-specific term and $\varepsilon_{i t}$ is an error term.

In the model, past firm value, firm size and leverage act as the endogenous variables, while the other variables are exogenous. The selection of the endogenous variable and the exogenous variable is according to Magee (2013) and Ayturk et al. (2016).

This study extends the model to include the interaction terms between derivatives and managerial ownership and other possible interactions to examine whether there is a significant positive relationship between derivatives and managerial ownership that influences firm value.

$$
\begin{aligned}
& Q_{i t}=\beta_{0}+\beta_{1} Q_{i t-1}+\beta_{1} \mathrm{DER}_{i t}+\beta_{2} \mathrm{MO}_{i t}+\beta_{3}(\mathrm{DER} \times \mathrm{MO}) \\
& +\beta_{4}(\mathrm{DER} \times \mathrm{LEV})+\beta_{5}(\mathrm{DER} \times \mathrm{GROWTH})+\beta_{6} \mathrm{ACCES}_{i t} \\
& +\beta_{7} \mathrm{RISK}_{i t}+\beta_{8} \mathrm{SIZE}_{i t}+\beta_{9} \mathrm{GROWTH}_{i t}+\beta_{10} \mathrm{LEV}_{i t}+\eta_{i}+\varepsilon_{i t}
\end{aligned}
$$

where $(\mathrm{DER} \times \mathrm{MO})$ is the interaction term between derivatives and managerial ownership. Adam and Fernando (2006) and Lievenbrück and Schmid (2014) employed the interaction between derivatives and managerial ownership to examine the increase in firm value when managers used hedging instruments to manage firm risk exposure. (DER $\times$ LEV) is the interaction between derivatives and leverage. Lau (2016) and Gilje and Taillard (2017) reported that derivatives have a differential effect on firm value based on leverage. Following this, they tested the interaction between leverage and derivatives and found its significance on firm value. Then (DER $\times$ GROWTH) is the interaction between derivatives and investment growth following Lau (2016), Lin and Smith (2007) and Gilje and Taillard (2017). They reported that the hedging strategy of high growth firm is designed to increase its investment position. 
The empirical model is developed to examine the relationship between derivatives and firm value and the interaction between derivatives and managerial ownership and its impact on firm value. This study employs system-generalized method of moments (GMM) for dynamic panel data as proposed by Arellano and Bover (1995) and Blundell and Bond (1998). This method is effective when the moment conditions are exercised in the model framework and the data with a certain number of moment conditions are specified for the model. Therefore, panel GMM provides a solution for the endogeneity issues by substituting the endogenous variables with instrumental variables. System-GMM offers better elasticity to the variance-covariance framework and has greater effectiveness, improves accuracy and addresses endogenous issues in the model (Baltagi, 2005). This study also performs several diagnostic tests that include the validity test of the instruments and serial correlation test as recommended by Arellano and Bover (1995) and Blundell and Bond (1998). The Hansen test is employed to check the validity of the instruments used, while $\operatorname{AR}(1)$ and $\operatorname{AR}(2)$ are for the serial correlation tests. Hansen test has null of valid instruments, while $\mathrm{AR}(1)$ and $\mathrm{AR}(2)$ have nulls of the absence of first- and second-order serial correlation in the residuals, respectively. The absence of second-order serial correlation, particularly the AR(2) confirms the regression model is robust (Arellano and Bover, 1995).

\section{Empirical analysis and discussions}

Table 1 presents the descriptive statistics (overall) of the variables used in the analysis. The sample comprises 200 firms from the main market of Bursa Malaysia. First, the mean for Tobin's $Q$ is 1.1829 with standard deviation (SD) of 1.3763 implying that the firms are profitable, on average. The mean of total derivatives is 53.0956, SD of 197.4415 and the mean for managerial ownership is $8.0842 \%$, SD equals to $14.2923 \%$, indicating a lower managerial ownership in the sample firms. The mean and SD of access to financial market are $0.7333 \%$ and $44.24 \%$, respectively. The mean for firm risk shows $32.79 \%$ with SD of $17.26 \%$, denoting lower risk for the firms. Then, the mean reported for firm size is 13.8753 with SD of 2.0318 , while the mean for investment growth is $10.92 \%$ with SD of $38.93 \%$. The mean values for leverage and SD are $38.41 \%$ and $75.58 \%$, respectively. Based on Table 2 on

\begin{tabular}{lccccc}
\hline Variables & Observation & Mean & Standard deviation & Min & Max \\
\hline Tobin's $Q$ & 1,187 & 1.1829 & 1.3763 & 0.0420 & 15.0664 \\
DER & 959 & 53.0956 & 197.4415 & 0.0003 & 5509.834 \\
ROA & 1,164 & 0.0633 & 0.1005 & -0.5059 & 2.1222 \\
ROE & 1,164 & 0.1006 & 0.2299 & -1.3361 & 4.3117 \\
MO & 1,111 & 8.0842 & 14.2923 & 0 & 71.9 \\
ACCESS & 1,200 & 0.7333 & 0.4424 & 0 & 1 \\
RISK & 1,176 & 0.3279 & 0.1726 & 0.0597 & 2.0503 \\
SIZE & 1,187 & 13.8753 & 2.0318 & 0.0002 & 20.4546 \\
GROWTH & 1,184 & 0.1092 & 0.3893 & 3.4200 & 7.3267 \\
LEV & 983 & 0.3841 & 0.7558 &
\end{tabular}

Note(s): Tobin's $Q$ is a measurement for firm value; ROA and ROE are alternate measurements for firm value; DER is total derivatives (notional value/total asset); MO is managerial ownership (total shareholding (direct) owned by managers over the total common shares outstanding), ACCESS is access to financial market (firm that pays dividend in the present year equals to " 1 " and " 0 " otherwise); RISK is firm risk (average standard deviation of daily stock returns on the previous year and then annualized to yearly return); SIZE is firm size (natural logarithm of total assets); GROWTH is investment growth (ratio of capital expenditure to sales) and LEV is leverage (long-term debt divided by total shareholder's equity)

Table 1.

Summary of descriptive statistics (overall) 
JABES 28,4

the descriptive statistics (sectors), the technology sector records the highest use of derivatives during the study period with mean and SD of 87.3401 and 127.1806, respectively, while trading and services records the lowest with mean of 26.9312 and SD of 37.4548.

This study reports the correlation coefficients between the independent variables in Table 3. The result indicates that the multicollinearity problem is not a concern due to low correlation coefficients between the independent variables; thus, the model is not biased.

This study presents model (1) and model (2) in Table 4, estimated through the systemGMM estimator. Model (1) includes derivatives (DER) and managerial ownership (MO) as the independent variables together with ACCESS, RISK, SIZE, GROWTH and LEV as the control variables. In model (2), this study incorporates the interactions between the DER $\times$ MO, DER $\times$ LEVERAGE, DER $\times$ GROWTH, in addition to the variables as in model (1).

The diagnostic tests are reported at the bottom of Tables 4 and 5 . Based on the tests, there is no issue on the validity of the instruments and autocorrelation in the residuals. Hansen test shows that the null hypothesis is not rejected; hence, the instruments are valid. Furthermore, the $\mathrm{AR}(1)$ and $\mathrm{AR}(2)$ tests expose the absence of autocorrelation in the model.

\subsection{Hypotheses tested: H1. There is a significant positive relationship between hedging via derivatives and firm value, as proposed by the hedging theory}

The results in Table 4 provide evidence on the influence of derivatives and managerial ownership on firm value. Based on model (1), derivatives is positively significant on firm value $(\phi<0.05)$. Managerial ownership is also found to have positive significance on firm value $(\phi<0.05)$. As for the control variables, this study documents a robust and expected positive relationship with firm value. This finding therefore provides evidence on the effective hedging activities via derivatives adopted by the firms, hence increasing firm value, consistent with Allayannis and Ofek (2001), Bartram et al. (2011), Chong et al. (2014), Bhagawan and Lukose (2017), Tanha and Dempsey (2017) and Seok et al. (2020). The positive relationship between derivatives and firm value could be due to several reasons; firstly, firms use derivatives to hedge risk exposure and financial volatility (Lau, 2016) and secondly, firms with higher risk use more derivatives instruments to hedge risk in order to maintain firm value (Bhagawan and, 2017). While Chong et al. (2014) mentioned that no firm can avoid the encountering risk and hedging is a complementary strategy to mitigate risk that is faced by the firm. Besides, this finding is in support of the hedging theory stating that firms that expose to risk are more likely to use derivatives to increase firm value. Thus, the finding confirms that derivatives have a positive relationship with firm value, and $H 1$ is supported. As for managerial ownership, a positive significance with firm value $(\phi<0.05)$ indicates managers attempt to reduce the risk affecting the return on their investment in the firms. This finding is in line with Adam and Fernando (2006), Ameer (2010), Coles et al. (2012) and Lel (2012).

\subsection{Hypotheses tested: H2. There is a significant positive relationship between derivatives and managerial ownership (interaction) that influences firm value, as proposed by the managerial aversion theory}

The estimated result for model (2), the model with interactions, is also reported in Table 4 . The interaction is incorporated (DER $\times \mathrm{MO}$ ) to investigate the role of managers toward decision in using derivatives to protect firm value. In the interaction specification, the relationship between derivatives and managerial ownership is negative and significant $(p<0.01)$. This finding therefore contradicts the managerial aversion theory; $H 2$ therefore is not supported. Managerial aversion theory states that managers tend to use derivatives in managing the risk of the firms to protect themselves and not to essentially benefit the shareholders. The 

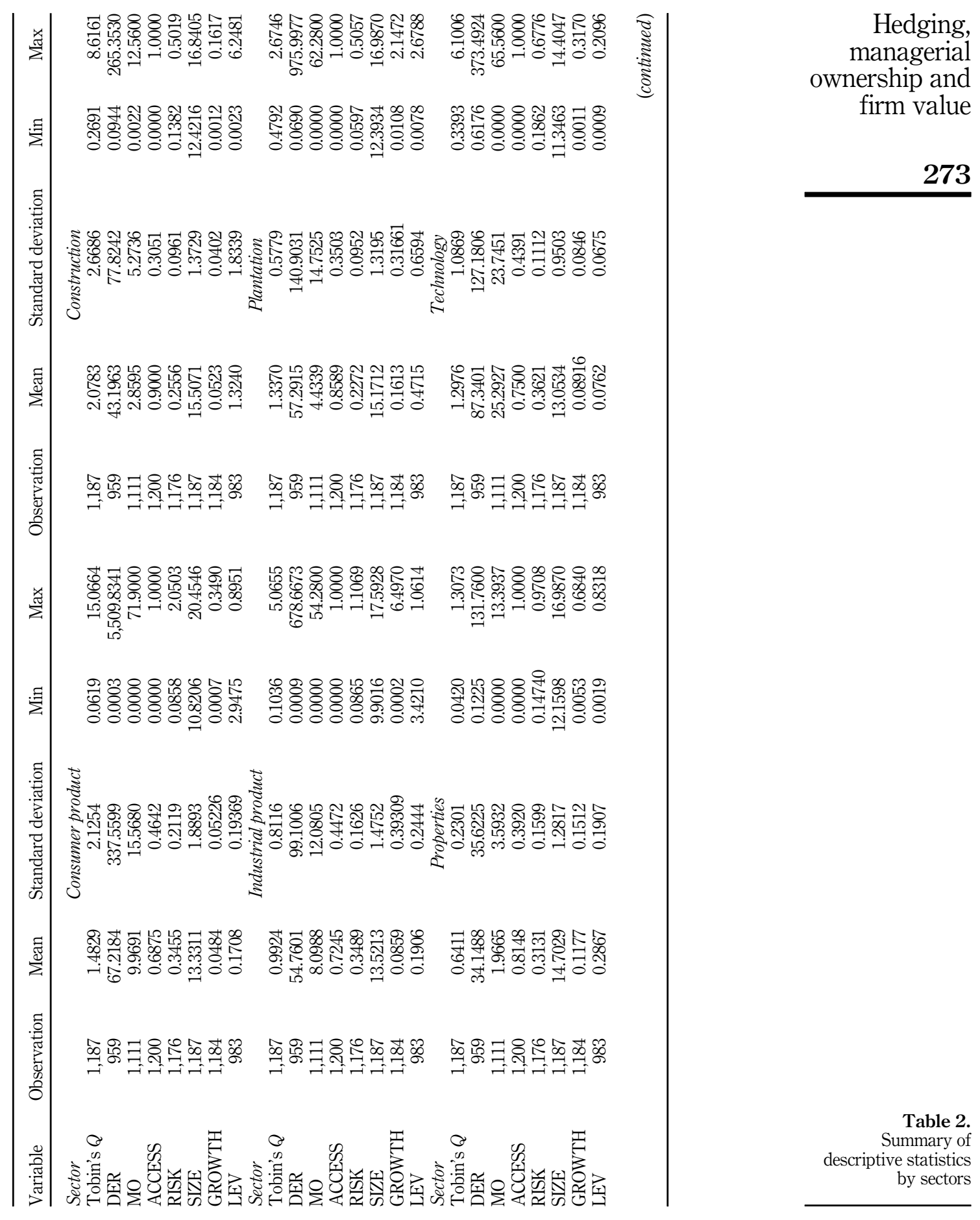

Table 2. Summary of descriptive statistics by sectors 
JABES

28,4

274

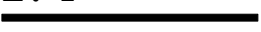

Table 2.

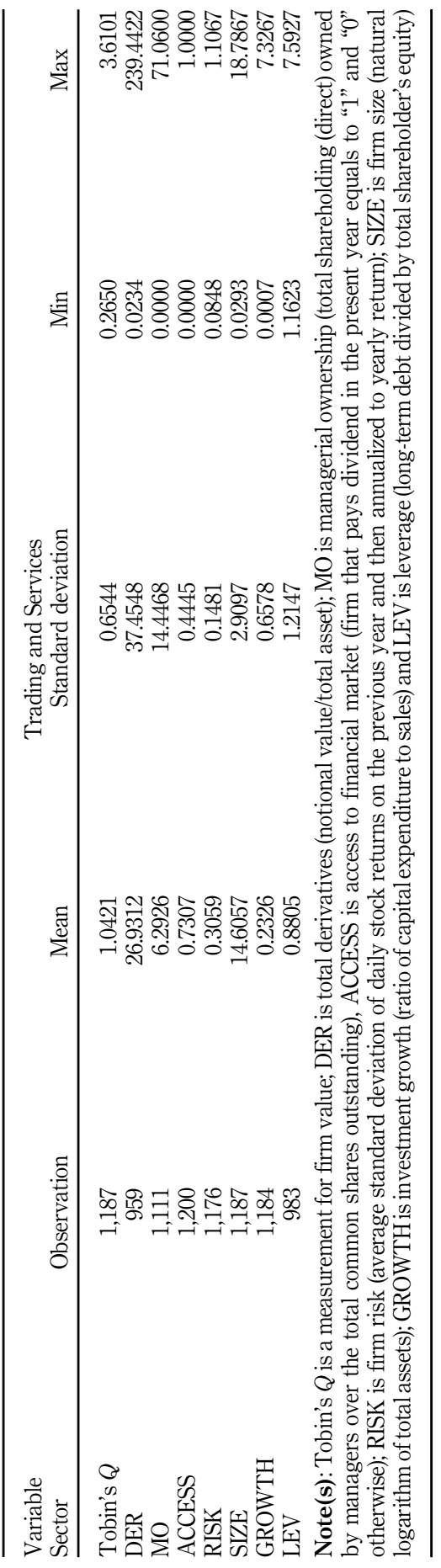


significant negative interaction between derivatives and managerial ownership on firm value suggests that managers less hedge when they have higher ownership (Seng and Thaker, 2018). In line with this argument, Ameer (2010) claims that Malaysian managers do not comprehend the upside of taking positions in the derivatives market and they prefer to use consultants to determine their organization's risk appetite before making decision on the derivatives market. This study therefore documents empirically that managerial ownership plays a less important role in the decision of firms to engage in derivatives.

Hedging, managerial ownership and firm value

275

\begin{tabular}{|c|c|c|c|c|c|c|c|}
\hline & DER & $\mathrm{MO}$ & ACCESS & RISK & SIZE & GROWTH & LEV \\
\hline DER & 1.0000 & & & & & & \\
\hline MO & 0.0333 & 1.0000 & & & & & \\
\hline ACCESS & 0.0326 & $-0.0852^{* * * *}$ & 1.0000 & & & & \\
\hline RISK & -0.0230 & $0.1309 * * * *$ & $-0.4846^{* * * *}$ & 1.0000 & & & \\
\hline SIZE & $-0.0563^{*}$ & $-0.2432^{* *}$ & $0.2658^{* * * *}$ & $-0.3978^{* * * *}$ & 1.0000 & & \\
\hline GROWTH & -0.0111 & -0.0098 & -0.0293 & -0.0479 & 0.0450 & 1.0000 & \\
\hline LEV & $-0.0984^{* * * *}$ & -0.1290 *** & -0.0017 & $-0.1495^{* * *}$ & $0.3298^{* * * *}$ & $0.1018^{* * * *}$ & 1.0000 \\
\hline
\end{tabular}

Note(s): *,**, *** represent the significance at level $p<0.1, p<0.05, p<0.01$

Table 3.

Correlation coefficients among independent variables

\begin{tabular}{lcc}
\hline Variables & Model 1 & Model 2 \\
\hline Tobin's $Q(-1)$ & $0.819^{* * *}(53.99)$ & $0.799^{* * *}(125.44)$ \\
DEV & $0.0006^{* *}(2.57)$ & $0.0016^{* * *}(19.93)$ \\
MO & $0.0037^{* *}(2.46)$ & $0.0071^{* * *}(14.87)$ \\
ACCESS & $0.167^{* * *}(5.62)$ & $0.0682^{* * * *}(17.46)$ \\
SIZE & $-0.0495^{* * *}(-12.95)$ & $-0.0378^{* * *}(-31.39)$ \\
GROWTH & $-0.110^{* * *}(-14.35)$ & $-0.101^{* * *}(-22.12)$ \\
LEV & $0.233^{* * *}(18.04)$ & $0.256^{* * *}(32.15)$ \\
RISK & $0.219^{* * *}(3.18)$ & $0.315^{* * *}(7.63)$ \\
DER $\times$ MO & & $-0.0001^{* * * *}(-17.55)$ \\
DER $\times$ GROWTH & & $-0.0004^{* * * *}(-4.16)$ \\
DER $\times$ LEV & $0.604^{* * *}(8.63)$ & $-0.0033^{* * * *}(-24.85)$ \\
Constant & 640 & $0.489^{* * *}(18.36)$ \\
The number of observations & 94 & 640 \\
The number of instruments & 170 & 119 \\
The number of groups & 0.013 & 170 \\
AR $(1)$ & 0.107 & 0.014 \\
AR (2) & 0.235 & 0.148 \\
Hansen test & & 0.158
\end{tabular}

Note(s): ***** represent the significance at level $p<0.1, p<0.05, p<0.01$; $t$-statistic is in bracket; Tobin's $Q$ is measurement for firm value; DER is total derivatives (notional amount/total asset); MO is managerial ownership (total shareholding (direct) owned by managers over the total common shares outstanding), ACCESS is access to financial market (firm that pays the dividend in the present year equals to " 1 " and " 0 " otherwise); RISK is firm risk (average standard deviation of daily stock returns on the previous year and then it has been annualized to yearly return); SIZE is firm size (natural logarithm of total assets); GROWTH is investment growth (ratio of capital expenditure to sales); LEV is leverage (long-term debt divided by total shareholder's equity); DER $\times$ MO is the interaction between total derivatives and managerial ownership; DER $\times$ LEV is the interaction between total derivatives and leverage; DER $\times$ GROWTH is the interaction between total derivatives and investment growth

Table 4. Regression result (system-GMM) 
JABES

28,4

276

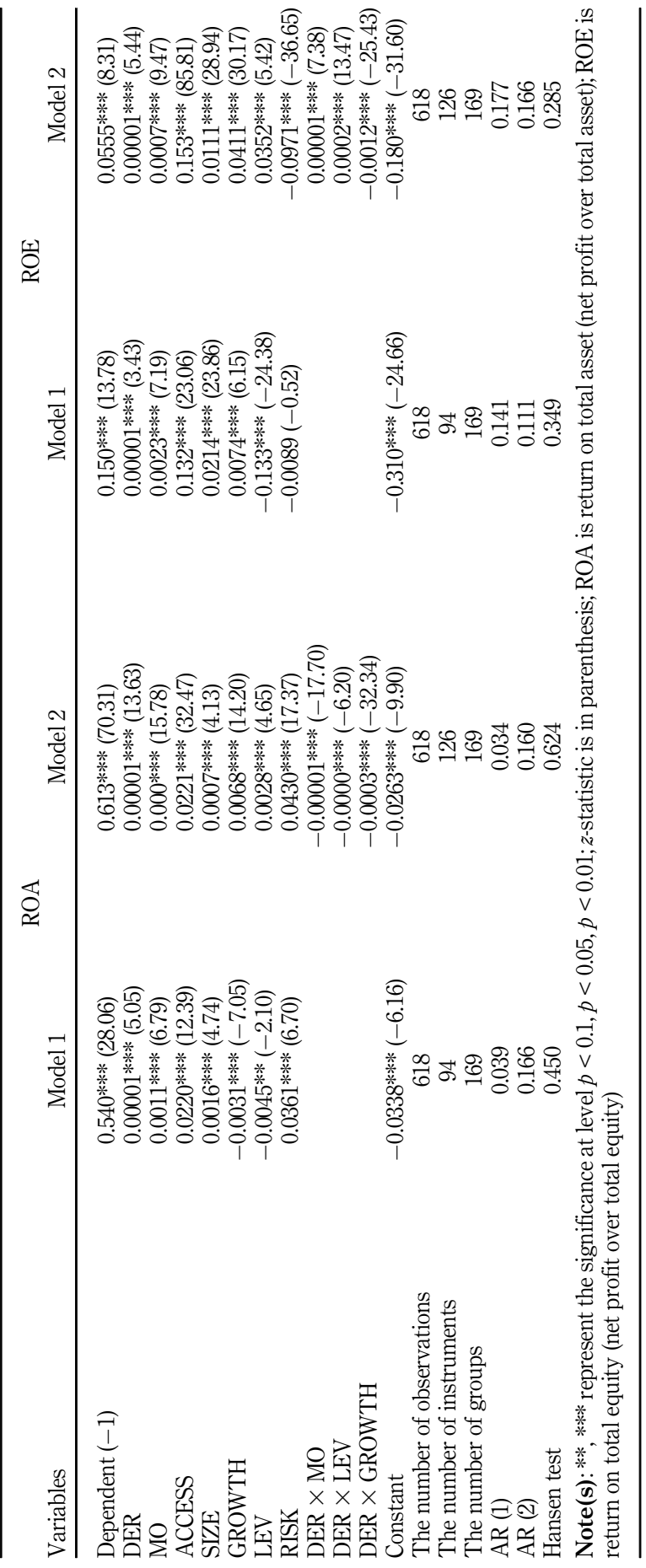

Table 5.

Robustness test (ROA and ROE) 


\subsection{Robustness test}

This study performs a robustness test to check the consistency of the result (Tobin's $Q$ ) with alternate measurements of firm value, i.e. return on asset (ROA) and return on equity (ROE), shown in Table 5 . The robustness tests are to reinforce reported results that the use of derivatives among Malaysian firms may affect the firm value and the influence of managerial ownership on hedging decision that eventually influence firm value. Model 1 (ROA and ROE) further confirmed the results (Tobin's $Q$ ) that the use of derivatives among Malaysian firms positively affects the firm value $(\phi<0.01)$ [1]. The interaction result of model 2 (ROA) also indicates negative significance between derivatives and managerial ownership on firm value $(p<0.01)$. Overall, the results based on ROA and ROE are consistent with Tobin's $Q$.

\section{Conclusion, limitation and future research}

This study examines the effect of risk management using derivatives on firm value and the interaction between derivatives and managerial ownership on firm value based on 200 sample firms that engaged with derivatives instruments during the period 2012-2017. Prior to the issuance of MFRS 7 (Financial Instrument: Disclosure) which took effect on January 2012, past studies on derivatives engagement among Malaysian firms depend on the nonmandatory disclosure of derivatives position in the annual reports of firms. Most of the past studies on derivatives among Malaysian firms therefore suffered from data inaccuracy since the reporting on hedging positions was not made mandatory prior to 2012. Firms therefore may not report their hedging positions, although they may engage in derivatives at that time. The current study unlike the previous studies on Malaysian firms is able to avoid this concern by using data on derivatives beginning of 2012 .

Results of the study are robust based on the various regression models and measurements on firm value (Tobin's $Q, \mathrm{ROA}$ and $\mathrm{ROE}$ ). This study found evidence that derivatives have a significant positive relationship with firm value. However, derivatives when interact with managerial ownership have a significant negative effect on firm value. This suggests that Malaysian managers hedge less when they have higher ownership, partly contributed by the hedging complexity and the unfamiliarity with the instruments.

This study focuses on the derivatives, which consist of foreign currency derivatives, interest rate derivatives and commodity derivatives. Nevertheless, this study focuses only on managerial ownership that is deemed relevant and important to the Malaysian firms, while other forms of ownership also exist in Malaysia. Therefore, the result may not apply to other types of ownership. In this light, future research on the types of derivatives instruments could be carried out in greater length and depth. In addition to that, this study also proposes to investigate other forms of ownership such as state-/foreign owned and institutional ownership on hedging and impact on firm value.

Overall, this study has important implications to managers and investors. First is on the importance of risk management via derivatives to increase firm value, second, the influence of derivatives engagement and managerial ownership on firm value and finally, the quality reporting on derivatives engagement by firms in line with the required accounting standard set by regulators.

\section{Note}

1. The small coefficients of DER $(\phi<0.01)$ on ROA and ROE are due to the wide difference in ratio measurements of variables (DER against ROA, ROE) causing the numerator to be much smaller compared to the denominator in the computation of beta coefficient. DER is measured according to the ratio of notional value of the derivatives contracts (RM) over total asset, with mean of 53.0956. ROA and ROE are measured based on the ratio of net profit over total asset and net profit over share holders' equity, with mean values of 0.0633 and 0.1006 , respectively. A 1 unit increases in DER hence increases ROA and ROE only by 0.00001 unit, other variables constant.

\section{Hedging, managerial ownership and firm value}


JABES

28,4

\section{References}

Abdullah, A. and Ismail, K.N.I.K. (2017), "Company-specific characteristics and the choice of hedge accounting for derivatives reporting: Malaysian case", International Journal of Accounting, Auditing and Performance Evaluation, Vol. 30 No. 3, pp. 280-292.

Adam, T.R. and Fernando, C.S. (2006), "Hedging, speculation, and shareholder value", Journal of Financial Economics, Vol. 81 No. 1, pp. 283-309.

Alkebäck, P., Hagelin, N. and Pramborg, B. (2006), "Derivative usage by non-financial firms in Sweden 1996 and 2003: what has changed?", Managerial Finance, Vol. 32 No. 2, pp. 101-114.

Allayannis, G. and Ofek, E. (2001), "Exchange rate exposure, hedging, and the use of foreign currency derivatives", Journal of International Money and Finance, Vol. 20 No. 2, pp. 273-296.

Allayannis, G. and Weston, J.P. (2001), "The use of foreign currency derivatives and firm market value", The Review of Financial Studies, Vol. 14 No. 1, pp. 243-276.

Allayannis, G., Lel, U. and Miller, D.P. (2011), "The use of foreign currency derivatives, corporate governance, and firm value around the world", Journal of International Economics, Vol. 87 No. 1, pp. 65-79.

Ameer, R. (2010), "Determinants of corporate hedging practices in Malaysia", International Business Research, Vol. 3 No. 2, pp. 120-130.

Ameer, R., Isa, R.M. and Abdullah, A. (2011), "A survey on the usage of derivatives and their effect on cost of equity capital", The Journal of Derivatives, Vol. 19 No. 1, pp. 56-71.

Antônio, R.M., Lima, F.G., dos Santos, R.B. and Rathke, A.A.T. (2019), "Use of derivatives and analysts' forecasts: new evidence from non-financial Brazilian companies", Australian Accounting Review, Vol. 29 No. 1, pp. 220-234.

Arellano, M. and Bover, O. (1995), "Another look at the instrumental variable estimation of errorcomponents models", Journal of Econometrics, Vol. 68 No. 1, pp. 29-51.

Ayturk, Y., Gurbuz, A.O. and Yanik, S. (2016), "Corporate derivatives use and firm value: evidence from Turkey”, Borsa Istanbul Review, Vol. 16 No. 2, pp. 108-120.

Bae, S.C. and Kim, H.S. (2016), "Foreign currency debt financing, firm value, and risk: evidence from Korea surrounding the global financial crisis", Journal of Financial Studies, Vol. 45 No. 1, pp. 124-152.

Bae, S.C., Kim, H.S. and Kwon, T.H. (2017), "Currency derivatives for hedging: new evidence on determinants, firm risk, and performance”, The Journal of Future Market, Vol. 22 No. 1, pp. 1-21.

Baltagi, B.H. (2005), Econometrics Analysis of Data, John Wiley and Sons, West Sussex.

Barton, J. (2001), "Does the use of financial derivatives affect earnings management decisions?", Accounting Review, Vol. 76 No. 1, pp. 1-26.

Bartram, S.M. (2019), "Corporate hedging and speculation with derivatives", Journal of Corporate Finance, Vol. 57 No. 1, pp. 9-34.

Bartram, S.M., Brown, G.W. and Conrad, J. (2011), "The effects of derivatives on firm risk and value", Journal of Financial and Quantitative Analysis, Vol. 46 No. 4, pp. 967-999.

Belghitar, Y., Clark, E. and Mefteh, S. (2013), "Foreign currency derivative use and shareholder value", International Review of Financial Analysis, Vol. 29 No. 1, pp. 283-293.

Berkman, H. and Bradbury, M.E. (1996), "Empirical evidence on the corporate use of derivatives", Journal of Financial Management, Vol. 25 No. 2, pp. 5-13.

Bhagawan, P.M. and Lukose, P.J. (2017), "The determinants of currency derivatives usage among Indian non-financial firms: an empirical study", Studies in Economics and Finance, Vol. 34 No. 3, pp. 363-382.

Blundell, R. and Bond, S. (1998), "Initial conditions and moment restrictions in dynamic panel data models", Journal of Econometrics, Vol. 87 No. 1, pp. 115-143. 
Bodnar, G.M., Hayt, G.S. and Marston, R.C. (1998), "1998 Wharton survey of financial risk management by US non-financial firms", Financial Management, Vol. 27 No. 4, pp. 70-91.

Bouwman, C.H.S. (2014), "Managerial optimism and earnings smoothing", Journal of Banking and Finance, Vol. 41 No. 1, pp. 283-303.

Brunzell, T., Hansson, M. and Liljeblom, E. (2011), "The use of derivatives in Nordic firms", European Journal of Finance, Vol. 17 Nos 5-6, pp. 355-376.

Choi, J.J., Mao, C.X. and Upadhyay, A.D. (2013), "Corporate risk management under information asymmetry", Journal of Business Finance and Accounting, Vol. 40 Nos 1-2, pp. 239-271.

Chong, L.L., Chang, X.J. and Tan, S.H. (2014), "Determinants of corporate foreign exchange risk hedging”, Managerial Finance, Vol. 40 No. 2, pp. 176-188.

Chung, K.H. and Pruitt, S.W. (1994), “A simple approximation of Tobin's Q”, Financial Management, Vol. 23 No. 3, pp. 70-74.

Coles, J.L., Lemmon, M.L. and Felix Meschke, J. (2012), "Structural models and endogeneity in corporate finance: the link between managerial ownership and corporate performance", Journal of Financial Economics, Vol. 103 No. 1, pp. 149-168.

Dakhlallh, M.M., Rahid, N., Wan Abdullah, W.A. and Al Shehab, H.J. (2020), "Audit committee and Tobin's Q as a measure of firm performance among Jordanian companies", Journal of Advanced Research in Dynamical and Control Systems, Vol. 12 No. 1, pp. 28-41.

Demarzo, P.M. and Duffie, D. (1995), "Corporate incentives for hedging and hedge accounting", The Review of Financial Studies, Vol. 8 No. 3, pp. 743-771.

Fahlenbrach, R. and Stulz, R.M. (2009), "Managerial ownership dynamics and firm value", Journal of Financial Economics, Vol. 92 No. 3, pp. 342-361.

Fazillah, M., Azizan, A. and Hui, S. (2008), "The relationship between hedging through forward, futures and swaps and corporate capital structure in Malaysia”, ICFAI Journal of Derivatives Market, Vol. 5 No. 2, pp. 37-52.

Gastineau, G. and Kritzman, M. (1999), Dictionary of Financial Risk Management, Fabozzi Associates, New York.

Geczy, C., Minton, B.A. and Schrand, C. (1997), "Why firms use currency derivatives", Journal of Finance, Vol. 52 No. 4, pp. 1323-1354.

Ghosh, A. (2017), "How do derivative securities affect bank risk and profitability?", The Journal of Risk Finance, Vol. 18 No. 2, pp. 186-213.

Gilje, E.P. and Taillard, J.P. (2017), "Does hedging affect firm value? Evidence from a natural experiment", Review of Financial Studies, Vol. 30 No. 12, pp. 4083-4132.

Haron, R. (2018), "Do Muslim directors influence firm performance? Empirical evidence from Malaysia”, Al Shajarah, (Special Issue Islamic Banking and Finance), pp. 283-305.

Haushalter, D.G. (2000), "Financing policy, basis risk, and corporate hedging", The Journal of Finance, Vol. 55 No. 1, pp. 107-152.

Lau, C.K. (2016), "How corporate derivatives use impact firm performance?", Pacific-Basin Finance Journal, Vol. 40 No. 1, pp. 102-114.

Lel, U. (2012), "Currency hedging and corporate governance: a cross-country analysis", Journal of Corporate Finance, Vol. 18 No. 2, pp. 221-237.

Lievenbrück, M. and Schmid, T. (2014), "Why do firms (not) hedge? Novel evidence on cultural influence”, Journal of Corporate Finance, Vol. 25 No. 1, pp. 92-106.

Lin, C.M. and Smith, S.D. (2007), "Hedging, financing and investment decisions: a simultaneous equations framework", Financial Review, Vol. 42 No. 2, pp. 191-209.

Magee, S. (2013), "Foreign currency hedging and firm”, Batten, J.A., MacKay, P. and Wagner, N. (Eds.), Advanced in Financial Risk Management, Palgrave Macmillan, London, pp. 57-80. 
JABES 28,4

Mian, S.L. (1996), "Evidence on corporate hedging policy", Journal of Financial and Quantitative Analysis, Vol. 31 No. 3, pp. 419-439.

Modigliani, F. and Miller, M.H. (1958), "The cost of capital, corporation finance and the theory of investment", The American Economic Review, Vol. 48 No. 3, pp. 261-297.

Nguyen, H. and Faff, R. (2002), "On the determinants of derivative usage by Australian companies", Australian Journal of Management, Vol. 27 No. 1, pp. 1-24.

Nguyen, H. and Faff, R. (2010), "Does the type of derivative instrument used by companies impact firm value?", Applied Economics Letters, Vol. 17 No. 7, pp. 681-683.

Seng, C.K. and Thaker, H.M.T. (2018), "Determinants of corporate hedging practices: Malaysian evidence", Report on Economics and Finance, Vol. 4 No. 4, pp. 199-220.

Seok, S.-I., Kim, T.-H., Cho, H. and Kim, T.-J. (2020), "Determinants of hedging and their impact on firm value and risk: after controlling for endogeneity using a two-stage analysis", Journal of Korea Trade, Vol. 24 No. 1, pp. 1-34.

Sheedy, E. (2006), "Corporate risk management in Hong Kong and Singapore", Managerial Finance, Vol. 32 No. 2, pp. 89-100.

Siddika, A. and Haron, R. (2020), "Capital regulation and ownership structure on bank risk", Journal of Financial Regulation and Compliance, Vol. 28 No. 1, pp. 39-56.

Smith, C.W. and Stulz, R.M. (1985), "The determinants of firms' hedging policies”, Journal of Financial and Quantitative Analysis, Vol. 20 No. 4, pp. 391-405.

Stulz, R.M. (1984), "Optimal hedging policies”, Journal of Financial and Quantitative Analysis, Vol. 19 No. 2, pp. 127-140.

Supanvanij, J. and Strauss, J. (2010), "Corporate derivative use and the composition of CEO compensation”, Global Finance Journal, Vol. 21 No. 2, pp. 170-185.

Tanha, H. and Dempsey, M. (2017), "Derivatives usage in emerging markets following the GFC: evidence from the GCC countries", Emerging Markets Finance and Trade, Vol. 53 No. 1, pp. 170-179.

\section{Corresponding author}

Razali Haron can be contacted at: hrazali@iium.edu.my

For instructions on how to order reprints of this article, please visit our website:

www.emeraldgrouppublishing.com/licensing/reprints.htm

Or contact us for further details: permissions@emeraldinsight.com 